\title{
Political Accidents in Zimbabwe
}

\author{
JOOST FONTEIN \\ Department of Anthropology and Development Studies, University of Johannesburg
}

\section{Introduction}

On 16 August 2011 Zimbabwe awoke to the news that retired General Solomon Mujuru, aka Rex Nhongo (his war alias), the former deputy commander of ZANLA (Zimbabwe African National Liberation Army) and independent Zimbabwe's first black army commander, husband of the (then) vice-president, Joice Mujuru, longterm confidante of (then) president Robert Mugabe, and widely regarded as 'kingmaker' with the Zimbabwe African National Union Patriotic Front (ZANU PF), had died in a mysterious fire at his farm in Beatrice, $60 \mathrm{~km}$ south west of Harare. Just four days later, on 20 August, amid public statements of grief from across the political spectrum, and growing speculation about the cause of his death, Mujuru's remains were buried at the National Heroes Acre in Harare at a huge state funeral attended by tens of thousands of people. After the 'inexplicable, horrendous fire accident' as Mugabe then described it ${ }^{1}$ - there was only a 'small pile of charred bones and ash' to be buried, and workers reportedly needed 'shovels to scrape his remains off the floor.' 'Burnt beyond recognition', unconfirmed reports suggested dental records were needed to confirm his identity; ${ }^{3}$ and (unusually for state funerals in Zimbabwe) the 'coffin remained sealed. ${ }^{4}$ Nevertheless, the closed casket did little to contain the plethora of rumours that emerged in the months that followed, which remain unresolved, despite police investigations and an official inquest.

In this article, I use Mujuru's death as way into discussing 'political accidents' in Zimbabwe's recent history, in order to explore the efficacies of rumours and the politics of uncertainty in relation to what I tentatively term the unfinished nature of death in Zimbabwe. Mujuru's death is useful because the controversies that surrounded it, and the official inquest that followed, which continue to be the subject of great speculation both in print and on social media, ${ }^{5}$ turn not only on the inconsistencies of different witness accounts, and the woeful incompetence of the police and fire brigade's response to the fire, but also on their failure to secure forensic evidence properly, the contested role of the state-appointed pathologist, the unresolved mysteries of the

\footnotetext{
'Mugabe Calls for Peace as Mujuru is Buried', Talk Zimbabwe.com, 20 August 2011.

'Solomon Mujuru's Death Alarms Moderates', Mail \& Guardian, 19 August, 2011.

'Mujuru Death "Accident"', Times (SA), 21 August, 2011. In fact, it is unclear if dental records were used to identify him although samples were taken. Later, after his burial, DNA tests were also conducted in South Africa, and compared against samples taken from his relatives.

'Doubts Raised About Mujuru’s Cause of Death', Mail \& Guardian, 6 February 2012.

5 Here I rely primarily on reports that appeared in local and international newspapers, many of which were published and accessed online. As veteran Zimbabwean journalist Geoffrey Nyarota has lamented, the government's clampdown on press freedom, and the political polarisation of the media, contributed to the 'rumour mill' and 'pure speculation' about Mujuru's death. Journalists became deeply involved in this, often conflating news and social-media reports in obscure ways. See G. Nyarota The Graceless Fall of Robert Mugabe: The End of a Dictator's Reign (Cape Town: Penguin, 2018), Ch. 7.
} 
fire itself, and the obscurities of Mujuru's burnt remains, all of which later provoked (unfulfilled) family demands that his remains be exhumed and re-examined. This illustrates how, in the context of a long history of factionalism in ZANU PF, rumour and dissent can turn on the indeterminacy of material substances, as much as on, or rather in entanglement with, contested narratives and representations. The two are of course intertwined. In this article, I suggest that the productive uncertainties provoked by such 'political accidents' - which constitute a particular kind of death in Zimbabwe - reflect and perhaps reinforce broader (epistemological and ontological) uncertainties that surround all death in Zimbabwe, and perhaps elsewhere, indicating that death is, in a sense, never finite, never complete, interminable, and potentially always in the (un/re)making.

I begin by outlining the main events of Mujuru's death, and the controversies it provoked, before situating this in a longer history of unresolved 'political accidents' in Zimbabwe. While Mujuru's death was undoubtedly an unusually controversial event in recent Zimbabwean history, and one already subject to academic and popular analysis, ${ }^{6}$ it does fit a broader pattern of what I call 'political accidents', a particular kind of death that points to the productive and potent, yet often disruptive, duplicitous and excessive indeterminacy that can surround all death. I return to this below.

\section{Factionalism, rivalries and murky business dealings}

On 16 August 2011, Zimbabwe's state-owned daily newspaper, the Herald, announced that 66 year old Solomon Mujuru had died in a suspected fire outbreak at his farm in Beatrice.7 The report described how a 'sombre atmosphere engulfed the farm' where his wife, Joice Mujuru, other family members, and a collection of senior ZANU PF officials had gathered. ${ }^{8}$ The Herald carried quotes from these ZANU PF visitors that reflected both their sense of profound shock and great loss, signalling the start of an intense period of hagiographic outpouring from across Zimbabwe's political divides. State security minister, Sydney Sekeramayi, said it was 'hard to believe' that 'one of Zimbabwe's greatest sons is no more', while the information and publicity minister, Webster Shamu, described the death as 'a tragedy which is difficult to fathom', noting that Mujuru was 'synonymous with the history of the whole liberation struggle ... a very brave fighter and illustrious son of the soil'. Such sentiments were not reserved to ZANU PF. In his message of condolence, the now late Morgan Tsvangirai, then leader of the opposition Movement for Democratic Change (MDC) and prime minister in the Government of National Unity (GNU) (which lasted from 2009 to

6 See Nyarota, Graceless Fall; B.-M. Tendi, 'State Intelligence and the Politics of Zimbabwe's Presidential Succession' African Affairs 115, 459, 2016, 203-224; C. B. George The Death of Rex Nhongo (London: Quercus, 2015).

'Solomon Mujuru Dies' Herald, 16 August 2011.

8 Including home affairs minister Kembo Mohadi, state security minister Sydney Sekeramayi, information and publicity Minister Webster Shamu, Youth development, indigenization and empowerment minister Saviour Kasukuwere, defence-force commander Constantine Chiwenga, air-force commander Perence Shiri, director general of the Central Intelligence Organisation Happyton Bonyongwe, ZANU PF spokesperson Rugare Gumbo, and provincial chairperson of ZANU PF for Mashonaland East Ray Kaukonde. 'Solomon Mujuru dies' Herald, 16 August, 2011. 
2013), described as 'tragic' the loss of 'a patriot who served his country with honour and distinction', a 'true and gallant son of the soil.' ${ }^{9}$ For his part, Dumiso Dabengwa of the Zimbabwe African People's Union (ZAPU) (who had left ZANU PF in 2008 to reform ZAPU) commented that Mujuru 'never feared criticising the party' and had 'played no part in massacres of opposition supporters in the Matabeleland provinces in the 1980s. ${ }^{10}$ Others described Mujuru as not only Zimbabwe's most highly decorated general, but a widely respected businessman and successful farmer. For many international diplomats and others, he represented a 'moderate' face of ZANU PF, particularly as international efforts increased during the years of the GNU to reengage with Zimbabwean politics.

Yet even on that first day, not all of the reports were quite so hyperbolic. One described Mujuru as 'among Zimbabwe's most feared men"11 and even Ibbo Mandaza, an academic and political commentator perceived by many to be close to Mujuru, described him as 'Machiavellian' in his behind-the-scenes efforts to secure presidential succession for his wife, then the vice-president. ${ }^{12}$ Journalist, Lance Guma suggested that Zimbabweans were 'divided' over Mujuru's 'mixed bag' legacy, pointing to the 'empire of farms, mines, properties and other business interests' the general had 'amassed' since retiring from the army in the 1990s. ${ }^{13}$ Others pointed to his alleged involvement in dubious business deals linked to the establishment of Zimbabwe's mobile phone networks in the 1990s, the controversial acquisition of River Ranch diamond mine, and the alleged laundering of 'diamond plunder' and illegal gold from the Democratic Republic of Congo. ${ }^{14}$

These emerging uncertainties about the nature of Mujuru's 'legacy' would continue for months and even years, particularly when family inheritance struggles loomed after it emerged Mujuru, a notorious womaniser, had a second wife and more than twenty children out of wedlock. ${ }^{15}$ But even more prominent in reports emerging that first morning after his death, were multiple questions about the 'mysterious circumstances ${ }^{16}$ of the death, and its potential consequences. 'It's a huge shock. The suspicion of power play is everywhere' said Eddie Cross of the MDC, 'Everybody's talking

9 'Prime Minister Morgan Tsvangirai's Condolence Message' 16 August, 2011, The Zimbabwe Situation https://www. zimbabwesituation.com/old/aug17_2011.html (accessed 10 September 2018).

10 'Zimbabwe 'King-maker' General Dies in Fire' Daily Telegraph, 16 August 2011. Dabengwa repeated this claim in an interview with me in Bulawayo in August 2015.

11 'Mujuru was Among Zimbabwe's Most Feared Men' Radio Voice of the People, 16 August 2011.

12 I. Mandaza, 'Mujuru: A Leader Who Made, Unmade History' Zimbabwe Independent, 18 August 2011.

13 L. Guma 'General Solomon Mujuru Legacy Divides Opinion' SW Radio Africa, 16 August 2011. This empire included the farm where Mujuru died, which was acquired 'violently' from Guy Watson-Smith in 2001. Watson-Smith was made to leave 'with only his briefcase'. All his assets on the farm, from furniture to irrigation equipment, were sold off by Mujuru. Later, lawyers acting for Watson-Smith 'were attacked and assaulted' when they filed a high-court application against Mujuru. Guma also described a defamation case Mujuru brought against Horizon magazine, during which Mujuru allegedly told the court, 'if I had known white people [namely Horizon's editor Andy Moyse] had defamed me, I would have shot them'

14 Guma, SW Radio Africa, 16 August 2011.

15 'Mujuru Spills the Beans' Daily News, 6 May 2012; 'Mujuru Most Patient Woman in Marriage: Mugabe' New Zimbabwe, 5 May 2012; 'Tempers Flare over Mujuru Estate' Newsday, 21 March 2015. Some reports implied that as many as ninety children had come forward to make a claim on Mujuru's estate, and this too fed back into rumours about his death, with some insinuating that his wife Joice was involved because she wanted to control his vast wealth (see 'CIO Accused by Baba Jukwa of Killing Solomon Mujuru Admits That Mujuru's Death Was Planned' My Zimbabwe, 9 April 2015, https://www.myzimbabwe.co.zw/ videos-pics/3526-man-accused-by-baba-jukwa-of-killing-solomon-mujuru-admits-that-mujuru-s-death-was-planned.html (accessed 12 November 2018).

16 'Zimbabwe's General Solomon Mujuru dies in fire', Mail \& Guardian, 16 August 2011. 
about it ... it's a huge event and could spark violence between factions of ZANU PF. ${ }^{17}$ The Mail \& Guardian of 16 August 2011 reported that his death occurred at 'a politically sensitive time $\ldots$ as the country grapples with a timeline for its next general election' pointing to intensifying ZANU PF factionalism then aligning differently around when to hold the next elections, as well as the thorny question of who might eventually succeed Robert Mugabe. Unlike Grace Musila's book on the 1988 murder of Julie Ward in Kenya, ${ }^{18}$ which identifies a sharp differentiation between UK and international discourses about Ward's death, and those taking place within Kenya, both international and Zimbabwean media reports quickly linked Mujuru's death to internal factionalism and the looming succession debate. While the UK's Daily Telegraph of 16 August suggested that Mujuru's death 'could intensify turmoil in ZANU PF over who will succeed Mr Mugabe', the now late Zimbabwean political analyst John Makumbe told the BBC that the death of 'Zimbabwe's "king-maker" would likely result in 'more fragmentation in Zanu-PF', pointing to the 'fierce rivalry' between Solomon Mujuru and Emmerson Mnangagwa, then the defence minister. Indeed, many quickly suggested that the 'the most obvious beneficiaries' of Mujuru's death were members of the faction led by Mnangagwa, ${ }^{19}$ whilst others pointed to the weakened position that Joice Mujuru now found herself in. ${ }^{20}$

Looking back from the time of writing (in August 2018) - seven years after Mujuru's death; four years after Joice Mujuru's unprecedented removal from the vice-presidency and ZANU PF in 2014 (in large part because of Grace Mugabe's vitriolic interventions); nine months after Mnangagwa's own removal from the vicepresidency in November 2017 (after Grace Mugabe turned her crass attention to her new rival), and the spectacular, military 'non-coup' that followed, which removed Mugabe from office (as well as his wife and her so-called G40 faction) and replaced him with Mnangagwa as president and General Chiwenga as his deputy; and less than a month after yet another controversial election (July 2018) - these particular predictions about Joice Mujuru's vulnerability appear, at least for the moment, to have been correct. Certainly, in the wake of Mujuru's death, ZANU PF's succession disputes followed a decidedly changed trajectory, and any confidence that once may have existed that Joice Mujuru would succeed Mugabe, has long since evaporated.

In 2011, however, the abundance of possibilities, rumours and uncertainties meant that 'the way he has gone' was indeed 'difficult to comprehend', as General Chiwenga, put it the morning after the death. Simply (or perhaps especially) within ZANU PF, let alone outside of it, there is 'so much in-fighting ... now that if it's foul play', commented one MDC member, 'it's anybody's guess who might have done this. ${ }^{21}$ Chiwenga himself was later fingered in rumours about Mujuru's death in an unconfirmed report allegedly compiled by Zimbabwe's Central Intelligence Organisation

D. Smith 'Zimbabwe's Ruling Party Shrouded in Suspicion After Ex-Military Chief Dies' Guardian, 16 August 2011.

G. A. Musila, A Death Retold in Truth and Rumour: Kenya, Britain and the Julie Ward Murder (London: James Currey, 2015).

'General's Death Opens Mugabe Succession Race' Financial Times, 16 August 2011.

Smith, Guardian 16 August 2011.

Smith, Guardian 16 August 2011. 
(CIO). ${ }^{22}$ This came amid suggestions that he too had presidential ambitions but had encountered deep opposition from an 'old guard' within the armed forces. BlessingMiles Tendi has since argued that factionalism between Mnangagwa and Mujuru was reflected in long-running tensions between Zimbabwe's military intelligence, allegedly aligned to Mnangagwa, and elements of the civilian CIO linked to Mujuru - a point that both affirms the efficacy, and yet casts doubt on the veracity, of the unconfirmed CIO report. ${ }^{23}$

As early as August 2011, rumours circulated that Chiwenga was running a 'hit squad' to 'assassinate anyone that he views as an obstacle', and linked Mujuru's demise to the attempted assassination of Air Marshal Perence Shiri three years earlier. ${ }^{24}$ Suspicions about Mujuru's death quickly reached fever pitch, and Zimbabwe's Independent newspaper cited 'a senior Zanu PF politburo member' as saying that Mujuru's allies were almost certain he was murdered. 'This is political murder, call it assassination, by other definitions, the anonymous source said. 'You must put this death in the context of the attempted murder of (Air Marshal Perence) Shiri a few years ago. ${ }^{25}$

Accusations of foul play are seldom far from Zimbabwe's political discourse, and involve allegations of treason and assassination almost as often as actual deaths. The prominent use of such accusations by ZANU PF to marginalise perceived threats, both within its own ranks (such as against Joice Mujuru before her 2014 ouster and against Mnangagwa in November 2017, but also in counter attack by Mnangagwa against Grace Mugabe during the same period), and against opposition parties, Bishop Muzorewa in 1980, Ndabaningi Sithole 1997, and Morgan Tsvangirai in 2002, illustrates the long histories of factional intrigue and nefarious subterfuge that rumours surrounding Mujuru's death quickly drew from, slotted into, and contributed to.

Yet ZANU PF factionalism and succession debates were not the only issues being discussed the morning after Mujuru's death. Questions were also immediately raised about Mujuru's relationship with the president. The question of whether Mugabe had sanctioned an attack loomed very large. Although Solomon had long been one of Mugabe's closest confidantes, dating back to the role he played cementing Mugabe's authority within the guerrilla movement in the $1970 \mathrm{~s},{ }^{26}$ there had been reports 'that he may have fallen from grace after apparently meeting top US and UK diplomats in Harare. ${ }^{27}$ Not only had Solomon been indirectly implicated in the US Embassy cables scandal ${ }^{28}$ - which revealed that many senior ZANU PF figures (including Joice Mujuru) had been secretly meeting with US and other international diplomats -

'Chiwenga Ordered Mujuru Assassination' Nehanda Radio, 13 January 2012.

Tendi, 'State Intelligence'. The noticeable suppression of the police and the CIO, combined with the increasing prominence of the military since November 2017, and particularly the shooting of opposition protestors by soldiers in the wake of the July 2018 elections, supports Tendi's argument. However, rumours of a split between Mnangagwa and his now vice-president Chiwenga have since reiterated the complex and deeply fractured nature of ZANU PF.

24 'Chiwenga ordered Mujuru assassination' Nehanda Radio, 13 January 2012. See also 'Head of Zimbabwe Air Force Shot in Assignation Attempt on Close Mugabe Ally’ Daily Mail, 16 December 2008.

25 'Mujuru Allies Cry "Murder Most Foul"', Nehanda Radio/Zimbabwe Independent, 23 August 2011.

26 'Mugabe's bitterness towards Mujuru thickens murder plot', Zimbabwe Independent, 19 August 2016.

27 'Solomon Mujuru: Obituary if a Zimbabwean “king-maker” BBC News, 16 August 2011.

28 'Zanu-PF Ponders Retribution for WikiLeaks “Traitors”, Mail \& Guardian, 16 September 2011. 
suggestions also circulated that Mujuru had been forging relations with the MDC opposition in anticipation of a more 'moderate' post-Mugabe dispensation targeted to head off ZANU PF hardliners such as Mnangagwa and Chiwenga.

Suspicions also circulated that Mujuru had been a key actor in former finance minister Simba Makoni's flawed bid to stand as an independent candidate against Mugabe in 2008, on behalf of his Muvambo/Kusile/Dawn movement. Mujuru, many surmised, had been against Mugabe's candidacy in the 2008 elections. ${ }^{29}$ Although Makoni's 2008 efforts were ineffective, and never received the public support from Mujuru, or any other senior party member, that was rumoured to lay behind it, in 2011 many blamed Makoni and his 'hidden' supporters for ZANU PF's disastrous results at the March 2008 elections. All this suggested the relationship between Mugabe and Mujuru had indeed soured. Mugabe was said to fear his influence in the military and the politburo. Mujuru, it was often suggested, was the only man who dared to challenge or question Mugabe directly. In other words, for many, it was Mugabe himself who stood to gain most from Mujuru's untimely and mysterious demise. This was extenuated by a particular rumour that began with a Facebook post by Elliot Pfebve, an MDC-T activist, in which he erroneously claimed that two cabinet ministers, Saviour Kasukuwere and Supa Collins Mandiwanzira had been the last to talk to Mujuru alive, on Sunday 14 August, at a cricket match at Harare Sports club. As Nyarota discusses, this post 'perhaps fuelled most of the speculation that Mujuru was assassinated by people linked to Mugabe'; especially after it was published by Zimbabwe News Network, thereby also illustrating how news and social media became entangled in the 'habit of presenting idle speculation as the verified truth. ${ }^{30}$

Aside from factionalism, and his deteriorating relationship with the president, Mujuru's shady business dealings, particularly in relation to diamonds too quickly became the subject of intrigue. 'The plot further thickens', reported Zimbabwe's Independent, 'when it is taken into account Mujuru's most trusted diamond dealer Bothwell Hlahla died in a car accident in Mutare a few days before' the fire, and on the evening that Mujuru himself died, he was reportedly on his way to Beitbridge to meet international diamond dealers to 'resolve a dispute over payment for gems already sold'. ${ }^{31}$ But the world of murky diamond deals is rarely separate from the intrigues of ZANU PF's internal politics. It is well known that various branches of the party, as well as the state's military and security services, received controversial concessions at the Marange diamond fields and that different 'companies' run by party heavyweights have jostled to secure government-determined access over the last decade. Mujuru's business dealings undoubtedly meant he had many enemies, and these are hard to divorce from the political intrigues provoked by his mysterious death. All these different rumours intertwine in obscure ways, reflecting both how the uncertainty of rumours can have the effect of making almost anything seem

Indeed, in February 2008 it was reported that Mujuru was under 'house arrest' after 'media speculation grew linking Mujuru to rumours that the former finance minister Simba Makoni was planning a new party' 'Mujuru Under House Arrest' Zimbabwean, 13 February 2008.

30 Nyarota, Graceless Fall, 106, 108

31 'Mujuru Allies Cry “Murder Most Foul”, Zimbabwe Independent/Nehanda Radio, 23 August 2011. 
possible or conceivable, and how the politics of patronage, securocracy, corruption and factionalism are often perceived as deeply entangled. ${ }^{32}$

These rumours would persist, wax and wane in the following months and years, and remain unresolved. But it is both the speed with which they emerged in August 2011, and the trajectory they subsequently took that I draw attention to here. Indeed, if on 16 August questions were being raised about the mysterious circumstances of the fire, by the next day, media reports became much more direct, asking whether Mujuru had been assassinated and if so, by whom. ${ }^{33}$ On the same day, he was declared a national hero and his state funeral announced for Saturday 20 August. But tensions within ZANU PF were becoming a problem. Joice Mujuru herself was forced to publicly appeal for calm the following day, after ZANU PF youth marched to her home demanding government answers for her husband's mysterious death. Official denials that it was anything other than a terrible accident were considered unconvincing. As ZANU PF alarm about the explosiveness of the situation appeared to grow, the Herald was forced to pull a controversial article about the death, ${ }^{34}$ and the politburo issued a directive banning any party member, other than press secretary Rugare Gumbo, from commenting to the press. During the funeral itself, President Mugabe made an appeal for peace and calm, but this intervention did little to halt the intrigue, particularly because he himself expressed his own reservations after visiting Mujuru's burnt remains at the barracks of One Commando in Harare, an odd detail which would only emerge months later during the inquest in early 2012.

On 20 August, Mujuru was buried at the National Heroes Acre, attended by thousands of people. ${ }^{35}$ The funeral did little to dampen suspicions. A few days later, Tendai Biti, the finance minister and a senior member of the MDC, accused ZANU PF of orchestrating the death, claiming they had taken to 'roasting' their internal opponents. He later withdrew the remark. ${ }^{36}$ Within a few days, Joice Mujuru announced that she, too, was deeply suspicious about the death, and called for a new, more thorough police investigation. ${ }^{37}$ Within months, the Mujuru family would call for the exhumation of Solomon's remains and a new autopsy, as details of the police's bungled forensic investigations were revealed. The apparent rush to bury him within four days of his death caused further controversy. DNA tests confirming Mujuru's identity were only carried out after his burial, and as a result, the identity of the deceased became a major subject for the inquest's deliberations in early 2012.

Rumours and intrigue therefore did not cease after Mujuru's funeral, especially as more details about the fire and events around it were leaked to the press. The farm's

'Who killed Solomon Mujuru?', Blog post by R. Rotberg, 13 September 2011, https://robertrotberg.wordpress.com/2011/09/13/ who-killed-solomon-mujuru/ accessed 7 January 2017.

33 'Questions Over Mujuru Death' Daily News 17 August 2011; C. C. Mashiri, 'Was General Solomon Mujuru Assassinated?', Zimanalysis2009, 17 August 2011; L. Guma, 'Mujuru Death Raises More Questions Than Answers', SW Radio Africa, 17 August 2011.

34 'Herald Pulls the Plug on Mujuru Story as Tensions Run High', SW Radio Africa, 19 August 2011.

35 'Thousands of Zimbabweans Mourn Mujuru', Radio Voice of the People, 20 August 2011.

36 L. Guma 'Mugabe has the Most to Gain from Mujuru Death: Analyst', SW Radio Africa, 23 August 2011; 'The Mysterious Death of Solomon Mujuru and Fears for the Future of Zimbabwe', Telegraph (UK) 27 August 2011.

37 'Zimbabwe Vice-President Suspicious About Husband's Death', Voice of America News, 24 August 2011; 'Zim's Mujuru Demands Probe into Husband's Fiery Death', Mail \& Guardian, 24 August 2011. 
former owner, Guy Watson-Smith, contributed to the ferment by expressing his disbelief that Mujuru could not have easily escaped the burning building, given that it 'had more windows than holes in a colander. ${ }^{38}$ Police tried repeatedly to quell such speculations, as criticism mounted over the delay in releasing their investigation's findings. Concern about these delays mounted to such a degree that the issue was debated in parliament, and a new police investigation was launched in November but, as before, no details were released for public scrutiny. ${ }^{39}$ The police, it seemed, did not want to take responsibility and many suspected this reflected the political pressure they were under. Some suggested that the delays mirrored the March 2008 elections, when the official result was delayed while ZANU PF regrouped to unleash a terrible wave of violence that enabled them to secure their hold over power in the June 2008 presidential run-off. ${ }^{40}$

While 'in a country with a history of politically suspicious deaths ${ }^{31}$ it is not surprising that suggestions of foul play emerged quickly, it is striking how many of the rumours circulated around existing intrigues. Part of the context for the controversies enveloping Mujuru's death was therefore already in situ long before the fire took place. In the first few months after the death, official efforts to keep a lid on the rumours simply fuelled further speculation. This changed, however, with the public inquest in 2012, when details of the fire, the events around it, and of the police investigation, were finally made public. Then, as with the leaky, stinky human materials exhumed from the Chibondo mine earlier that year, ${ }^{42}$ the particular materialities of the death and its context - the farm's layout; the unexplained fire; the human remains burnt-beyond-recognition; guns apparently found next to the body; missing keys; contradicting witness statements; the flawed autopsy and problematic state pathologist; the failures of his VIP security and of the local police, fire service, and so on - all added further traction to the political uncertainties already surrounding Mujuru's demise.

\section{The inquest}

In early January 2012, after months of speculation, the attorney-general, Johannes Tomana, announced that police investigations 'are now complete and an inquest is set to begin soon'. The police report had been 'kept a closely guarded secret' and Tomana 'appealed to all interested parties ... to be patient and let the judicial process take its course'. The inquest would 'bring finality to a tragedy that shocked the entire

38 'Mujuru Allies Cry "Murder Most Foul", Nehanda Radio/Zimbabwe Independent, 23 August 2011; Joice Mujuru expressed similar sentiments, describing how their grandchildren used to climb in and out of the windows of the house. 'Zimbabwe VicePresident Suspicious About Husband's Death', Voice of America News, 24 August 2011.

39 'How Did Solomon Mujuru Die? Zim MPs Demand Answers', Mail \& Guardian, 6 November 2011; 'Mujuru’s Death Dominates Parly Debate', Herald, 11 October 2011; 'Mujuru Frustrated by Police Investigations Over Husband Death', Zimbabwe Daily, 7 November 2011, https://www.thezimbabwedaily.com/news/9562-mujuru-frustrated-by-police-investigations-over-husbanddeath.html (accessed 10 September 2018).

40 C. C. Mashiri 'Mujuru Death Probe is Like the 2008 Presidential Results', The Zimbabwe Situation, 29 August 2011, https://www. zimbabwesituation.com/old/aug30_2011.html\#Z20 (accessed 10 September 2018).

41 'Zimbabwe's Ruling Party Shrouded in Suspicion After Ex-Military Chief Dies', Guardian 16 August 2011.

42 J. Fontein, 'Remaking the Dead, Uncertainty and the Torque of Human Materials in Northern Zimbabwe' in F. Stepputtat (ed.), Governing the Dead: Sovereignty and the Politics of Dead Bodies (Manchester: Manchester University Press, 2014). 
nation. ${ }^{43}$ As with other inquests into unexplained deaths, ${ }^{44}$ it did nothing of the sort, but it gripped Zimbabweans' attention for the following three months. If anything, the inquest only fuelled suspicions of foul play by offering multiple points of traction through which the rumours could gain purchase. ${ }^{45}$

The inquest began on 16 January 2012, and was presided over by Magistrate Walter Chikana. The courtroom was spruced up, the toilets cleaned, running water was available, and heavy security was deployed in anticipation of the vice-president's attendance. ${ }^{46} \mathrm{~A}$ total of 42 witnesses were summoned to give evidence, including the vice-president. When the inquest opened, objections were immediately aired by the Mujuru family lawyer, Thakor Kewada, that they had not yet seen the police findings or witness statements to which they were legally entitled. The magistrate postponed the hearing to allow them 'time to peruse the report. ${ }^{27}$ When the inquest reopened, the police came in for heavy criticism from Kewada, particularly the three officers who formed Mujuru's official VIP security detail.

During their cross-examination, it emerged that, on discovering the fire, none of them had airtime to call the fire brigade, and their police radios had been out of order for six weeks. ${ }^{48}$ Furthermore, they did not know the layout of the homestead and so had 'opted to run three kilometres to the farm compound to get information on the location of his bedroom, instead of smashing windows to rescue him. ${ }^{39}$ Evidence emerged that Mujuru's relations with the three guards had been 'frosty' after they beat up one of his farmworkers. He had told his housekeeper, Rosemary Short, 'not to give them food because he was unhappy with the way they were carrying out their duties', and 'that there was virtually no security at the farm and that we were actually guarding ourselves..$^{50}$ Two of the policemen admitted they had been asleep, leaving their colleague alone on duty when the fire was discovered. ${ }^{51}$ The farm's southern gate was also unguarded ${ }^{52}$ and the police, stationed at the nearby town of Beatrice, had had no working vehicle for six months. A white commercial farmer from the area had been asked to help them reach Mujuru's farm after the alarm was raised..$^{53}$

More serious were contradictions between the police's statements and those made by Mujuru's staff, particularly Rosemary Short and Clemence Runhare, a private security guard. Both claimed they heard gunshots on the evening before the fire, which they had assumed was the VIP guards shooting snakes or warning off intruders,

43 'Mujuru Probe Complete But..., Newsday, 4 January 2012.

44 L. White, The Assassination of Herbert Chitepo: Texts and Politics in Zimbabwe (Bloomington, IA: Indiana University Press, 2003); Musila, A Death Retold; D. W. Cohen and E. S. A. Odhiambo, The Risks of Knowledge: Investigations into the Death of the Hon. Minister John Robert Ouko in Kenya, 1990, (Athens, OH: Ohio University Press, 2004).

45 In this section. I deliberately draw on a wide array of news reports which came out during the inquest because I am particularly interested in how the inquest fed into public debates about the death, rather than just in the inquest report itself.

46 'Heavy Police and Security Agents Presence at Mujuru Inquest', Radio Voice of the People, 18 January 2012; 'Mururu Inquest Changes Face of Courts', Daily News, 29 January 2012.

47 'Mujuru Inquest Temporarily Halted', SW Radio Africa, 18 January 2012.

48 'Mujuru Cop Makes Shocking Statement', EWN News, 18 January 2012.

49 'Mujuru Inquest Raises More Questions', Standard, 22 January 2012.

50 'Police Left Mujuru To Die - Lawyer', Daily News, 21 January 2012; 'I Heard Gunshots, Says Mujuru Maid', Daily News, 20 January 2012; 'Gen Mujuru feared Chihuri and his Officers: Maid', Zimbabwe Mail, 19 January 2012.

51 'Mujuru Wanted Police Guards Fired', New Zimbabwe, 19 January 2012.

52 'Independent Comment: Mujuru Inquest Exposes Police', Independent, 19 January 2012.

53 'New Evidence Suggests Mujuru Fire Not an Accident', SW Radio Africa, 24 January 2012. 
or came from poachers on nearby farms. Later that night, the police themselves dismissed these as the sounds of asbestos roofing cracking in the fire. ${ }^{54}$ Runhare also claimed that when Mujuru arrived at the farm's outer-perimeter fence earlier that evening, he was sober and accompanied by an unknown man. However, the policeman stationed 'at the inner-perimeter gate testified that Mujuru was drunk, alone in the vehicle and that a suit was draped over the passenger seat. ${ }^{55}$ Short insisted that 'Mujuru was not that drunk that he could not appreciate what was happening', adding that 'when he came home drunk' he would usually 'fall asleep upon parking his car.' ${ }^{56}$

The inquest also scrutinised Solomon's actions before arriving at the farm. $\mathrm{He}$ had apparently stopped off at a Beatrice motel on his way home from Harare. Several witnesses claimed that Mujuru, who was known to be fond of whiskey, had not been drunk when he left the bar. The bartender, Portia Kamvura, stated that Mujuru had ordered four whiskeys before setting off, saying he had to drive to Beitbridge early the next day for business. ${ }^{57}$ According to Douglas Nyakungu, an employee of the Zimbabwe Electrical Supply Authority (ZESA), who drank with Mujuru that night (and who later reappeared as an expert witness), the general had received a mysterious phone call that appeared 'serious, going by his facial expressions and hand movements. ${ }^{58}$ Further questions were raised about timing: why had it taken Mujuru forty minutes to reach his farm from Beatrice, a journey that would normally take only ten minutes?

Other details noted by his staff raised further questions. Short stated Mujuru had come to ask her for her keys to the house because he had left his own in Harare but his keys were later found in the burnt-out bedroom. He had not parked in his usual spot, stopping instead some distance from the kitchen door that he would have used to get into the house. Unusually, he had left his mobile phone, groceries and medication in the car, and had left the car unlocked. Short also contradicted suggestions that the fire had been started by a candle or a cigarette, noting that Mujuru was not carrying matches, did not smoke, and that there were no candles in the bedroom where the fire was believed to have started..$^{59}$

Amid the tension of the inquest there were lighter moments. Another security guard, Samuel Lewis, 'raised laughter in the courtroom' when he claimed he 'ran more than 300 metres in half a minute' to raise the alarm after the fire was discovered. ${ }^{60}$ But the inquest's first week was dominated by critical scrutiny of the police. The pressure on them was intense, and 'most of the [police] witnesses ... appeared visibly frightened ... speaking in very low tones' such that 'the magistrate had to ask $\ldots$ the police officers, to speak up. ${ }^{61}$ One was 'driven to the verge of tears under cross2012; 'I Heard Gunshots, Says Mujuru Maid', Daily News, 20 January 2012.

55 'Mujuru Inquest Adjourned with Anti-Climax Heading Towards a White-Wash', Zimbabwe Mail, 20 January 2012.

56 'Mujuru Sensed Death'. Daily News, 19 January 2012; 'Mujuru Inquest Raises More Questions', Standard, 22 January 2012.

57 'Fresh Evidence on Mujuru's Death', Daily News, 17 January 2012.

58 'Family Doubts Remains Belonged to Gen Mujuru', Independent, 26 January 2012.

59 'Mujuru "Wanted Police Guards Withdrawn"', Independent, 19 January 2012; 'I Heard Gunshots, Says Mujuru Maid', Daily News, 20 January 2012.

60 'Gen Mujuru feared Chihuri and his Officers: Maid', Zimbabwe Mail, 19 January 2012.

61 'Mujuru Inquest Temporarily Halted', SW Radio Africa, 18 January 2012. 
examination by Joice Mujuru and her relatives. ${ }^{\prime 2}$ Indeed emotions ran high for everyone. When Short claimed Mujuru had 'sensed that his death was coming', Solomon's brother Joel and sister Elizabeth 'failed to hold back their tears. ${ }^{63}$

The independent media scrutinised the 'shocking shortcomings in the calibre of personnel in the Zimbabwe Republic Police, ${ }^{64}$ and Pedzisai Ruhanya commented that 'Mrs Mujuru was now seeing first-hand how incompetent the police force was. ${ }^{65} \mathrm{But}$ such criticism was not reserved for the police, particularly when it emerged that the fire brigade had taken hours to arrive, and that when they did, they had no water because the tanks on their fire engines were leaky ${ }^{66}$ Beyond exposing the fact that ' $\mathrm{di}$ saster preparedness' was 'in a shambles, ${ }^{37}$ the independent media criticised the police for failing 'to properly investigate this gruesome murder of our liberation war hero' and for obstructing 'all possible leads and evidence to uncover what sounds like a political killing.6 ${ }^{68}$ Clearly, as more details emerged, suspicions were further fuelled that the inquest was 'heading towards a white-wash. ${ }^{69}$ Complaints also focused on state media coverage, prompting some to remark that the inquest could 'not be of any significance to ZANU PF', who were, Lovemore Madhuku claimed, 'not taking it seriously.70 In the same news report, others noted that politically motivated deaths were 'not new in ZANU PF. 'Remember when Tongogara died', Charles Mangongera explained, 'there was suspicion ... but after that the party soldiered on.' 'What we already have is a seeming case of cover up ... I doubt if there is going to be conclusive evidence'.

If the first week of the inquest failed to calm the rumours, these were enormously amplified in the following weeks as the inquest turned to the fire, Mujuru's corporeal remains and the state pathologist's report. Various expert witnesses gave evidence, including the fire brigade, ZESA officials, the state pathologist, and forensic scientists from South Africa. All raised further criticisms of the police's conduct at the scene and subsequent investigations. Early suggestions by police that a candle might have started the fire had already been undermined by Short's evidence. Later testimony by both fire-brigade and ZESA officials ruled out an electrical fault as a possible cause. Douglas Nyakungu, (the ZESA official drinking with Mujuru on the night of the fire) said investigations had shown that 'no ZESA equipment had started the fire' and that there was no evidence of overloading by 'high-currency appliances'. The fire had 'destroyed the electrical set up in the house' and not vice-versa. ${ }^{71}$ Meanwhile 'fire fighters testified that the flames ... were too intense to have been "just a normal fire", and 'no ordinary fire could have caused the roof to drop as it did. ${ }^{72}$ Harare's chief fire officer,

\footnotetext{
'General's Ghost Haunts ZANU-PF', Mail \& Guardian, 20 January 2012.

'Mujuru Sensed Death', Daily News, 19 January 2012.

'Independent Comment: Mujuru Inquest Exposes Police', Independent, 19 January 2012.

'Mujuru Inquest Temporarily Halted', SW Radio Africa, 18 January 2012.

'Mujuru Cop Makes Shocking Statement', EWN News, 18 January 2012.

'Mujuru Inquest: Zim Disaster Preparedness in a Shambles', Independent, 19 January 2012.

'Mujuru Inquest Temporarily Halted', SW Radio Africa, 18 January 2012.

'Mujuru Inquest Adjourned with Anti-Climax Heading Towards A White-Wash', Zimbabwe Mail, 20 January 2012.

'Mujuru Death Crisis', Daily News, 29 January 2012.

'Family Doubts Remains Belonged to Gen Mujuru', Independent, 26 January 2012.

'Fire Brigade Testimony Fuels Suspicion Over the Mujuru Fire', SW Radio Africa, 25 January 2012.
} 
Clever Mafoti, explained that their investigations had been inconclusive but had identified 'two sources of the fire in the main bedroom and the lounge'. Mafoti added that fires with two sources usually point to arson or an electrical fault. ${ }^{73}$ However, Mafoti noted, the "fire brigade could not definitely prove that theory because the crime scene ... had been contaminated by too many people.. ${ }^{74}$ By 'the time that we eventually arrived most of the leads had been destroyed' he added. ${ }^{75}$ Therefore, as Bothwell Mutandiro, director of Zimbabwe's police forensic section, later admitted to the inquest, 'the cause of the fire could not be determined. ${ }^{76}$

This uncertainty about the fire's cause and concerns about compromised evidence were echoed by forensic scientists from the South African Police Service (SAPS). They suggested 'the handling of evidence at the scene ... fell below professional standards. ${ }^{37}$ Lieutenant Colonel Lenong, chief forensic analyst at SAPS, ruled out explosives, and Seomyatseng Jack Maine said that tests on materials retrieved from the scene to ascertain whether 'accelerants' had been used, also showed no evidence. But, 'that was not to say any were not used', he stated, pointing to factors that could have 'compromised' the results, including how the samples were collected, the intense heat of the fire, and the incorrect storage plastic bags used by the police. ${ }^{78}$

These uncertainties about the fire were directly linked to uncertainties provoked by Mujuru's corporeal remains. Again, critical questions were raised about the competence of state investigators. Many witnesses spoke of unusually large, intense blue flames covering the burning human remains 'to a radius of about $30 \mathrm{~cm}$ around the body', which was discovered 'lying face down with both legs and arms severely burnt' in a passage near to the main bedroom. ${ }^{79}$ Tawanda Madondo, gardener at the farm, described finding a burning 'black object ... the shape ... of a human being', which needed 'a number of buckets ... to be extinguished' ${ }^{80}$ The number of buckets needed to douse the remains escalated from two to ten in different witness accounts. ${ }^{81}$ Constable Cletwell Garisai and Inspector Simon Dube 'told the inquest they poured at least ten buckets of water to douse the blue flame which was intense and became ferocious when water was poured on it.$^{82}$ Later Mafoti, from the fire brigade, explained that in fires above 500 degrees a 'triangle of combustion' could cause body fat to spontaneously combust with a blue flame, and that water poured on such an intense fire would immediately evaporate, causing the hydrogen in it to explode and intensify the flames. ${ }^{83}$

Gruesome descriptions were heard about the burnt remains, which were not easily identifiable. Indeed, Mujuru's identity had not been confirmed until DNA test

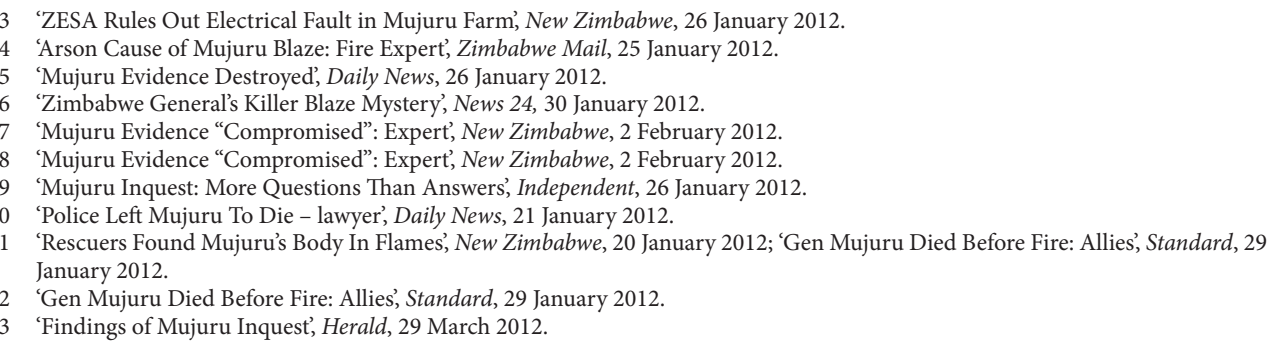


results were released several weeks after his burial. This was a point that Mujuru's brother Joel had raised repeatedly, even before the inquest began, claiming that he could not be confident that the body they had buried was that of his brother. These doubts were shared by many Zimbabweans in the country, and abroad. ${ }^{84}$ Even the inquest report noted that the police's decision to authorise burial before DNA tests had confirmed Mujuru's identity 'made no sense', was 'inappropriate' and an 'oversight' on their part. ${ }^{85}$

As the inquest continued more questions emerged. As the Zimbabwe Independent noted, 'the expert witnesses did nothing but raise more questions', ${ }^{86}$ for example, about why 'Mujuru's body burnt to ashes in two hours yet it takes over 11 hours to do an ordinary cremation in a confined environment. ${ }^{87}$ Others referred to a curious hole in Mujuru's stomach, and missing organs. Doubts were also raised by differing accounts of the extent to which his body had been burnt, the position it lay in, and whether the arms were raised. ${ }^{88}$ There were suggestions the body had been moved before the investigators arrived. ${ }^{89}$ Others queried why the carpet under the body was un- or less damaged by fire, indications for some (including for Mutandiro, director of Zimbabwe's police forensic section) 'that Mujuru died before the fire spread into the room where his remains were retrieved'. ${ }^{90}$ Equally contentious were the number of guns kept in the house: were there 14, 15 or $17 ?^{91}$ Were they all registered? And what about the guns allegedly found next to his body? ${ }^{92}$ And suggestions that spent ammunition had been found. ${ }^{93}$. These tied into comments about why a solider of Solomon's experience could not have escaped the burning building, something President Mugabe had raised at Solomon's funeral. ${ }^{94}$

The work of pathologist, Dr Gabriel Alviero Gonzalez, a Cuban doctor working at Parirenyatwa Hospital, who was drafted in to carry out the autopsy at One Command Barracks in Harare on 16 August 2011, received particular attention at the inquest. The Zimbabwe Independent summarised his testimony as follows:

84 'Mujuru Death Crisis', Daily News, 29 January 2012; see for example the online comment by mdcsoutheastlondon to the article, 'Zimbabwe General's Killer Blaze Mystery', News 24, 30 January 2012.

85 'Findings of Mujuru Inquest', Herald, 29 March 2012.

86 'Mujuru Inquest: Contradictions, More Suspicion', Zimbabwe Independent, 9 February 2012.

87 'Gen Mujuru Died Before Fire: Allies', Standard, 29 January 2012.

88 'Mujuru Inquest: More Questions Than Answers', Independent, 26 January 2012.

89 'New Evidence Suggests Mujuru Fire Not an Accident', SW Radio Africa, 24 March 2012.

90 'Mujuru Inquest: Contradictions, More Suspicion', Zimbabwe Independent, 9 February 2012.

91 'ZESA rules out electric fault in Mujuru fire', New Zimbabwe, 26 January 2018; 'Mujuru: Family Wants Second Opinion', New Zimbabwe, 28 January 2012; '17 Burnt Firearms Discovered at Mujuru’s House: Makedenge', Radio Voice of the People, 27 January 2012.

92 'General's Death Marked by Many Mysteries', IOL, 8 February 2012;, https://www.iol.co.za/news/africa/generals-death-markedby-many-mysteries-1229891 (accessed 7 December 2018); 'Two Guns Found Next To Mujuru’s Body', SW Radio Africa, 26 February 2012.

93 'Two Guns Found Next To Mujuru’s Body', SW Radio Africa, 26 February 2012; 'Mujuru: Family Wants Second Opinion', New Zimbabwe, 28 January 2012.

94 'Rare Unity at Funeral for Zimbabwean Hero Solomon Mujuru' Voice of America News, 19 August 2011. Although much more recently Mugabe told the Zimbabwe Independent that he thought Mujuru's 'careless' smoking must have caused the fire, as had happened during a well-known incident at a Geneva hotel in 1976 (see 'Robert Mugabe Finally Speaks on Solomon Mujuru's Death', PaZimbabwe, 24 March 2018. https://www.pazimbabwe.com/zimbabwe-45876-robert-mugabe-finally-speaks-onsolomon-mujurus-death.html; see also 'Robert Mugabe Refuses to Jump from The Fourth Floor of Geneva Hotel After Solomon Mujuru Started A Fire: Fay Chung Book Reveals Chilling Details', 26 March 2018. https://www.pazimbabwe.com/zimbabwe45957-robert-mugabe-refuses-to-jump-from-the-fourth-floor-of-geneva-hotel-after-solomon-mujuru-started-a-fire-faychung-book-reveals-chilling-details.html (both accessed 10 September 2018). 
A postmortem carried out by Dr Gabriel Alvero deduced the cause of death as 'carbonation due to open fire, origin unknown. The tracheal mucosa was red and black with carbon inside demonstrating that the deceased was alive when the fire started,' he said. Postmortem findings were: The right arm was complete but left arm was burnt to ashes up to the elbow level. Both lower limbs were burnt to ashes up to the knee level. The lungs were severely burnt and could not be recognized. The large vessels such as the aorta and vena cava were burnt and could not be recognized. The teeth were present but fragile and breaking off. The esophagus was severely burnt and could not be recognized. The stomach was burnt and absent. The pancreas was absent. The liver and gall bladder were present but severely burnt and charred. A portion of the bowel was present but damaged by action of the fire and heat. The kidneys were absent. The bladder was absent. The prostate was absent. The spleen was absent. No endocrine organ was found. ${ }^{95}$

While Gonzalez had identified no external injuries, others suggested that one of Mujuru's legs was broken. ${ }^{96}$ Some questioned why the autopsy had pointed to smoke inhalation as a possible cause of death, due to evidence of carbonisation in the mouth and throat, while other indications implied his lungs were still pink. ${ }^{97}$ The pathologist's status was also questioned when it emerged that he was not formally registered in Zimbabwe. ${ }^{98}$ Furthermore, the autopsy had been carried out without proper equipment, ${ }^{99}$ and no tests were done on the blood or organs because they were all burnt out. Amid this barrage of criticism of the bewildered Cuban pathologist, giving evidence through an interpreter, one of the oddest details to emerge was that President Mugabe had himself turned up, unannounced, just moments before the autopsy began, later telling journalists 'I have never seen a person die in such a horrific manner, we are all shocked. ${ }^{100}$ The pathologist testified that 'Mujuru appeared to have died from inhaling smoke', but added that his findings were inconclusive 'considering the state of the body.'101

The many official failings that the inquest revealed obviously fed the feverish rumour mill, and the Mujuru family repeated their demands for an exhumation and a new post mortem by an independent pathologist from South Africa, Dr Reggie Perumal, who was in court alongside their lawyer. ${ }^{102}$ Their court application was made even before the state pathologist had given evidence. Kewada questioned the Cuban pathologist's autopsy 'saying he had been in the country for only seven weeks and had a poor command of English', had been ill-equipped, and had 'bungled' the

\footnotetext{
95 'Mujuru Inquest: Contradictions, More Suspicion', Zimbabwe Independent, 9 February, 2012.

96 'Gen Mujuru Died Before Fire: Allies', Standard, 29 January 2012.

97 'Gen Mujuru Died Before Fire: Allies', Standard, 29 January 2012.

98 Nyarota, Graceless Fall, 110.

99 'Mugabe at Mujuru Post Mortem, Inquest Told', New Zimbabwe, 3 February 2012.

100 'Mugabe at Mujuru Post Mortem, Inquest Told', New Zimbabwe, 3 February 2012.

101 'Mujuru Exhumation Request Rejected', New Zimbabwe, 6 February 2012.

102 'Mujuru Evidence “Compromised”: Expert', New Zimbabwe, 3 February 2012.
} 
post mortem. ${ }^{103}$ Initially, Magistrate Chikwanha delayed responding to this request, saying it was 'premature' and evidence from the 'local pathologist' needed to be heard first. ${ }^{104}$ Later, Chikwanha denied the request altogether in an extraordinary outburst accusing Kewada 'of "violating" the Inquest Act', and arguing that 'to conclude that Dr Alviero [Gonzalez] had not carried out a proper job' was 'highly inappropriate'. The magistrate claimed that Kewada was not 'qualified' to 'address him 'over facts provided by witnesses', and would have to await until 'after the court has analysed all evidence', had made its 'conclusions on how the deceased met his death', and then sent 'recommendations to the AG's office.' ${ }^{105}$

After three weeks of testimony from 39 witnesses, the inquest ended with 'sharper contradictions and inconsistencies' and 'deepening suspicions of foul play' than it began with. ${ }^{106}$ Chikwanha's report was published at the end of the following month. It concluded that there was no evidence of 'foul play', and that Mujuru had died of 'carbonisation' from smoke from an open fire whose cause could not be determined.

Despite the suppositions, speculations, conjectures and suspicions by various people including the deceased's relatives, nothing concrete and no evidence at all was placed before the court to show that there was foul play in the death of the deceased. In addition to that there is evidence from the doctor that deceased did not suffer any other injuries besides that caused by fire and there is also the evidence from the lead investigator, Chief Superintendent Makedenge to the effect that they carried out exhaustive investigations but there was nothing to show that there was foul play leading to the death of the now deceased.

The facts and evidence presented before the court, therefore, do not show that there was foul play and consequently the court concludes that there was no foul play.

\author{
W. Chikwanha \\ Provincial Magistrate \\ 14 March $2012^{107}$
}

Following Chikwanha's report, the attorney general told the police to close the case. ${ }^{108}$ Mujuru's lawyer called the result a 'mockery' that failed to 'bring closure to the case. ${ }^{109}$ Despite continuing uncertainties and persistent demands from Joice Mujuru

\footnotetext{
103 'Mujuru Exhumation Request Rejected', New Zimbabwe, 6 February 2012; 'Mujuru Coroner Blasts Lawyer', New Zimbabwe, 6 February 2012.

104 'Magistrate Dismisses Request by Mujuru Family', SW Radio Africa, 30 January 2012.

105 'Mujuru Coroner Blasts Lawyer', New Zimbabwe, 6 February 2012.

106 'Mujuru Inquest: Contradictions, More Suspicion', Zimbabwe Independent, 9 February 2012.

107 Published in the Herald, 29 March 2012.

108 Nyarota, Graceless Fall, 109.

109 'Mujuru Inquest Results a Mockery: Family Lawyer', Radio Voice of the People, 17 March 2012.
} 
and the Mujuru family, ${ }^{110}$ no exhumation or re-examination of Mujuru's remains has ever taken place.

These continuing uncertainties link Mujuru's death to other unresolved, highprofile deaths in Zimbabwe and elsewhere. Indeed, they are a key aspect of the kind of 'political accident' that Mujuru's death epitomises, as I outline below. The inquest left the cause of death profoundly unresolved, and if anything, only extended the uncertainty, by offering in its minute account of the known and unknown aspects of the death, multiple points of traction for the swelter of suspicion and rumour to gain purchase. Indeed, as several commentators had already surmised, the inquest was never 'likely to bring finality' as the attorney-general had promised. This is partly because public inquests of this sort, although judicial, are usually not charged with identifying culpability but merely cause of death. This is important in a Zimbabwean context where deaths are very rarely understood as 'natural', whatever their immediate cause, and usually provoke difficult-to-resolve questions about intent and culpability. ${ }^{111}$ Pushing further, however, one could question whether the political and social functions of such public inquests really are about offering the kind of finality and closure the attorney-general had promised; a position that is akin to older anthropological arguments that see the function of death rituals as being about remaking society after the rupture of death. ${ }^{112}$

In contrast, I suggest that the inconclusive nature of the Mujuru death inquest, and others like it elsewhere, whatever the official pronouncements, is important for two reasons. Firstly, because this is how the politics of uncertainty surrounding death works, situated contingently between necro-politics and bio-politics - between the need for political legitimacy and the need to demonstrate necro-political sovereignty, impunity and capacity for fatal violence - such deaths must remain unresolved. They cannot be fixed as a named person or party's culpability as this would undermine the need for political legitimacy; yet by keeping rumours and suspicions of malevolent intent in circulation, this uncertainty contributes to 'necro-political power' by making rumoured culprits (or even just the very possibility that such a party exists) appear powerful, sovereign, and above the law.

As I have argued elsewhere (and below), this double effect was also key to the political efficacy of the war veteran-led 'vernacular' exhumations at Chibondo earlier in $2011 .{ }^{113}$ Here I suggest it is equally key to the efficacy of 'political accidents' as particular kinds of death in Zimbabwe. In both cases, this uncertainty turns, in part, on the 'excessivity' (Fontein), 'torque' (Pinney), 'indeterminate alterity' or 'otherness'

110 'Exhume Mujuru, Demands Family', Standard, 23 March 2012; 'Family Still Wants Mujuru Exhumed', Herald, 29 March 2012; 'They Murdered my Husband: Mujuru', Daily News, 23 February 2016; 'We'll Find Gen Mujuru Killers', Daily News 27 August 2015.

111 J. Fontein, 'Death, Corporeality, and Uncertainty in Zimbabwe' in A. Robben, (ed.) A Companion to the Anthropology of Death (London: Wiley, 2018); M. F. C. Bourdillon, The Shona Peoples, 1976 (Gweru: Mambo Press, 1987, 3rd ed.).

112 R. Hertz, Death and the Right Hand (New York: Free Press, 1960); M. Bloch, and J. Parry (eds), Death and the Regeneration of Life (Cambridge: Cambridge University Press, 1982).

113 Fontein, 'Remaking the Dead'; see also S. Eppel 'Repairing a Fractured Nation: Challenges and Opportunities in Post-GPA Zimbabwe' in B. Raftopoulos (ed.), The Hard Road to Reform. The Politics of Zimbabwe's Global Political Agreement (Harare: Weaver Press, 2013), esp. 231-232. 
(Renshaw) of human materials - what Pinney also calls the 'alterity of an enfleshed world' - which demands but ultimately elides easy determination or stabilisation into meaning. ${ }^{114}$ Filippucci et al. argue that the 'excessive metonymic qualities' of human materials often 'defy ... efforts to turn them into meaningful metaphors'. This explains why human remains

can be subject to huge and often highly specialised efforts and dramatic over-determinations into particular types of subjects/objects, such as ancestors, victims, heroes or specimens - processes that are often unusually problematic, politicized and contested. ${ }^{115}$

This was apparent both during the Chibondo controversies and the Mujuru inquest in the way that the manner in which human remains in both cases where handled, interpreted and 'reconstituted' was what provoked particular attention, debate and critique. ${ }^{116}$

Secondly, and related to this, the unresolvable and inconclusive nature of the Mujuru inquest is important because it exemplifies something that is maybe a feature of all death in Zimbabwe, and maybe all death in general. That it is never, or very rarely, entirely contained, stabilised, resolved, finished, or over and done with. That there always remains a contingent potentiality and uncertainty to death which defies material, semantic and temporal closure, and has to do with the way that death raises but cannot resolve difficult ontological questions about the imbrication of matter and meaning, and the entangled material and immaterial aspects of life.

Of course, these two reasons are intertwined, and therefore the profound ontological problems that death raises are what give the uncertainty of death its political traction, even if it also, ultimately, necessarily defies attempts to channel such political utility. While the key point here is that the uncertain or unfinished nature of death is politically productive, it also seems unlikely that any inquest could have resolved the burgeoning questions and intrigue surrounding Mujuru's demise.

114 Fontein, 'Remaking the Dead, 130; C. Pinney, 'Things Happen: Or, From Which Moment Does That Object Come?' in D. Miller (ed.), Materiality, (Durham, NC: Duke University Press, 2005), 256-272, at 270; L. Renshaw, Exhuming Loss: Memory, Materiality and Mass Graves of the Spanish Civil War (Walnut Creek, CA: Left Coast Press, 2011).

115 P. Filippucci, J. Harries, J. Fontein, and K. Krmpotich, 'Encountering the Past' in D. Shankland (ed.), Archaeology and Anthropology: Past, Present and Future (London: Berg, 2012), 197-218, at 211. There is a huge literature now on the politics of dead bodies, much of it heralded by K. Verdery's ground-breaking The Political Lives of Dead Bodies: Reburial and Post Socialist Change (New York: Columbia University Press, 1999). Subsequently, scholars have moved beyond Verdery's still rather passive emphasis on bodies as political symbols to focus on active dimensions of human materials, substances and corporeality (see, for example, Filippucci et al., 'Encountering the Past'; D. Posel and P. Gupta, 'The Life of the Corpse', African Studies. 68, 2009, 299-309; J. Fontein and J. Harries, 'The Vitality and Efficacy of Human Substances', Critical African Studies, 5, 3, 2013, 115-126; M. Salpeteur and J-P. Warner, 'Looking for the Effects of Bodily Organs and Substances through Vernacular Public Autopsy in Cameroon', Critical African Studies, 5, 3, 2013, 153-174. L. Major and J. Fontein, 'Corporealities of Violence in Southern and Eastern Africa', Critical African Studies, 7, 2, 2015, 89-98. See also the book series 'Human Remains and Violence', published by Manchester University Press, which includes: Stepputat, Governing the Dead; E. Anstett and J-M. Dreyfus, Destruction and Human Remains: Disposal and Concealment in Genocide and Mass Violence (2014); J-M. Dreyfus and E. Anstett, Human Remains and Mass Violence: Methodolgical Approaches (2015); J-M. Dreyfus and E. Anstett, Human Remains in Society: Curation and Exhibition in the Aftermath of Genocide and Mass-Violence (2017).

116 See Eppel, 'Repairing a Fractured Nation' for an account of the controversies surrounding Chibondo; see also Fontein, 'Remaking the Dead'. 


\section{A particular kind of death}

Mirroring what has frequently been reported within an innovative strand of research on road and traffic accidents across the region ${ }^{117}$ (part of a new literature reassessing meanings and practices of death across sub-Saharan Africa), ${ }^{118}$ fatal accidents in Zimbabwe, on roads or elsewhere, are often the subject of much public discussion, dissent, rumour, and sometimes occult accusation. Links between rumours, gossip, sorcery and 'the occult' are well established, ${ }^{119}$ as are the political imbrications of witchcraft accusations, ${ }^{120}$ but a key point here is that the uncertainties of such deaths often leak out of and across social, symbolic, discursive and political realms, and the uncontained materialities of bodies and persons can destabilise things, places, times, and landscapes as much as they question official and normative accounts of fatal events. This is what Jensen, in a different but not unrelated context, refers to as 'shimmering. ${ }^{121}$ Traces of past accidents are highly visible in the carcasses of vehicles on roadsides, but also appear through the uneasy presence of unsettled spirits and indeterminate ghosts said to haunt accident 'black spots,, ${ }^{122}$ themselves becoming dangers to be avoided or encountered at great risk.

There is an important link here to landscapes of terror associated with militia 'bases' and election violence. These too are also often reportedly haunted by ngozi (spirits) demanding atonement and reparation. ${ }^{123}$ Accidental and violent deaths are therefore linked by the haunted landscapes of terror they co-produce (literally and metaphorically) through the spilling of blood exemplifying the profound uncertainties that all deaths provoke. Indeed, as pointed out, death is rarely considered 'natural' in Zimbabwe. ${ }^{124}$ and is therefore very often accompanied by an excess of intrigue and contestation exactly because of the instabilities of personhood and society, bodies and spirit, material and immaterial, matter and meaning, that it can reveal. ${ }^{125}$ This is part of what I call the unfinished nature of death in Zimbabwe. ${ }^{126}$

These dynamics are reflected in how Zimbabwe's postcolonial milieu has long been punctuated by the 'accidental' deaths of politicians, army officers ${ }^{127}$ and other senior

117 M. Lamont, 'Accidents Have No Cure! Road Death as Industrial Catastrophe in Eastern Africa', African Studies, 71, 2, 2012, 174-194; M. Lamont, 'Speed Governors: Road Safety and Infrastructural Overload in Post-Colonial Kenya, c. 1963-2013', Africa, 83, 3, 2013, 367-384; A. Melnick, 'On Traffic Accident Blackspots in Kenya' Paper presented at the European Conference on African Studies, Lisbon, 27-29 June 2013; G. Klaeger, 'Introduction: The Perils and Possibilities of African Roads', Africa, 83, 3, 2013, 359-366; T. Sanders, 'Buses in Bongoland: Seductive Analytics and the Occult', Anthropological Theory, 8, 2008, 107-132.

118 R. Lee and M. Vaughan, 'Death and Dying in the History of Africa Since 1800', Journal of African History, 49, 3, 2008, 341-359; W. T. Kalusa and M. Vaughan, Death, Belief and Politics in Central African History. (Lusaka: Lembani Trust, 2013); M. Jindra and J. Noret (eds), Funerals in Africa (London: Berghahn, 2011).

119 P. J. Stewart, and A. Strathern, Witchcraft, Sorcery, Rumors and Gossip (Cambridge: Cambridge University Press, 2003).

120 S. Jensen, 'Shosholoza: Political Culture in South Africa Between the Secular and the Occult', Journal of Southern African Studies, $38,1,2012,91-106$.

121 S. Jensen, 'Corporealities of Violence: Rape and the Shimmering of Embodied and Material Categories in South Africa', Critical African Studies, 7, 2, 2013, 99-117.

122 Melnick, 'On Traffic Accident Blackspots'.

123 J. Fontein, 'Between Tortured Bodies and Resurfacing Bones: The Politics of the Dead in Zimbabwe', Journal of Material Culture, 15, 4, 2010, 423-448; see also, Eppel 'Repairing a Fractured Nation'; S. Eppel, 'Bones in the Forest' in Matabeleland, Zimbabwe: Exhumations as a Tool for Transformation', International Journal of Transitional Justice, 8, 3, 2014, 1-22.

124 Fontein, 'Death, Corporeality, and Uncertainty'; Bourdillon, The Shona Peoples.

125 Hertz, Death and the Right Hand.

126 Fontein, 'Death, Corporeality, and Uncertainty', 347.

127 For example, the late brigadier-generals Armstrong Paul Gunda and Fakazi Muleya; see 'Mugabe Honours Alleged Victims', Zimbabwean, 17 August, 2009. 
ZANU PF figures, such as Solomon Mujuru, which have provoked a fraught myriad of rumour and conspiracy about the ruling party 'eating their own. ${ }^{128}$ Although unusually high-profile, the controversies surrounding Mujuru's death echo very many other examples, including (to name only a few) the deaths of ZANU PF ministers and senior figures, Chris Ushewokunze in 1994, Zororo Duri in 1996; Border Gezi and Moven Mahachi in 2001; Brigadier General Paul Armstrong Gunda in 2007; and Elliot Manyika in 2008. ${ }^{129}$ More recently, in June 2013, just before the elections of that year, the outspoken ZANU PF MP Edward Chindori-Chininga died in a car accident only a week after the parliamentary committee he chaired released a 'damning report' into 'the abuse of diamond revenue from the Chiadzwa diamond fields.' ${ }^{130}$ All died in 'mysterious' accidents accompanied by rumours of foul play and assassination plots. Although I am mainly focused on the 'accidental' deaths high-profile ZANU PF officials, because this status is key to the 'political accidents' I am describing, there are also examples of suspicious deaths beyond the party which feed into the swelter of intrigue that can surround fatal car accidents, such as of senior ZAPU and ZIPRA figures in the 1980s, ${ }^{131}$ and more recently Susan Tsvangirai's death in a car accident in 2009, which some suspected was a botched attempt to assassinate her husband Morgan Tsvangirai. ${ }^{132}$ Another example illustrating how the unexplained deaths of much less high-profile party members can provoke similar controversy was that of aspiring ZANU PF parliamentary candidate Bruno Mugabe, just before the 2000 elections, when his car was washed away in a flash flood in Masvingo, which many suspected was intertwined with that province's infamous factionalism, and possibly occult interference. ${ }^{133}$

The point I am making is that these kinds of 'political accidents' constitute a particular kind of death that can be used as a lens through which to make sense of the unfinished nature of death in Zimbabwe. Controversial deaths of senior ZANU PF politicians are not only a feature of the last two decades, since Zimbabwe's turn towards 'authoritarian nationalism. ${ }^{134}$ There are many older unresolved deaths dating to the 'struggles within the struggle', which beset nationalist parties and guerrilla armies during the 1960s and 1970s. ${ }^{135}$ As with so much of contemporary Zimbabwean politics, the past looms large, close, and unresolved. Just as the burial of every new 'national hero' invokes recursive referral back to the nationalist politics of the 1960s and 1970s, so every new 'accidental' death renews the controversies of earlier unresolved deaths. Often these coincide exactly because such 'political accidents' have produced so many 'national heroes', an observation frequently noted in the media. ${ }^{136}$

\footnotetext{
128 'Mystery Surrounds Deaths of National Heroes', Nehanda Radio, 15 August 2012.

129 'Mystery Zim Car-Crash Deaths Haunt Zanu-PF', Mail \& Guardian, 27 June 2013.

130 'Secret Insider Warned ZANU PF “Rebel” Before His Death', Mail \& Guardian, 21 June 2013.

131 For example, Lookout Masuku, Sydeny Malunga Alfred Nikita Mangena, and ZAPU second vice-president Jason Ziyaphapha Moyo. See Nyarota, Graceless Fall; 'Mystery Zim Car-Crash Deaths Haunt Zanu-PF', Mail \& Guardian, 27 June 2013.

132 'Fatal Tsvangirai Crash "Was Not Accident” says MDC', Telegraph (UK), 7 March 2009.

133 'Battle for Masvingo Supremacy Resurfaces', Financial Gazette, 8 June 2000; also my fieldnotes from 2001.

134 B. Raftopoulos, 'The State in Crisis: Authoritarian Nationalism, Selective Citizenship and Distortions of Democracy in Zimbabwe' in A. Hammar, B. Raftopouos and S. Jensen (eds), Zimbabwe's Unfinished Business (Harare: Weaver Press, 2003).

135 M. Sithole, Zimbabwe: Struggles Within the Struggle (Harare: Rujeko Publishers, 1979).

136 'Mystery Surrounds Deaths of National Heroes', Nehanda Radio, 15 August 2012.
} 
Of all such deaths, the 1975 assassination of ZANU Chairman Herbert Chitepo in Lusaka, ${ }^{137}$ and the car accident that killed the popular ZANLA commander Josiah Tongogara in Mozambique in December 1979, on the eve of Zimbabwe's independence, remain subject to the fiercest controversies. Both are mired in rumours of ZANU power struggles, and are frequently the subject of media speculation. Zambia's deeply flawed 1976 Chitepo Commission Report blamed 'ethnic tensions' within ZANU, implicating Tongogara (and others) himself in Chitepo's death - a charge he went 'to his own unexplained death in 1979 still denying. ${ }^{138}$ In turn, it is often rumoured that Mugabe is haunted by Tongogara's ghost, implying that he had a hand in the guerrilla commander's death. ${ }^{139}$

Unlike other examples, Chitepo's death always was murder - it is hard to imagine how a car bomb could be reconstituted as an accident. Yet this murder was perhaps the archetypal kind of 'political accident' - the exception that proves the rule perhaps - because as White showed, ${ }^{140}$ the multiple confessions it led to, and the fact that its controversies not only endure but continually gain new meaning and salience, point exactly to the open-ended indeterminacy that death can provoke, even after 40 years. History is indeed 'a messy business' and 'there is no "perfect closure" to any event ${ }^{\text {'141 }}$ Furthermore, that so many different people, at different times, for different audiences, continue to claim or assign responsibility for Chitepo's assassination - 'fixing blame' to make possible a litany of diverse but inevitable partial 'national narratives $^{1442}$ - illustrates something of the political salience afforded by being associated in 'pavement radio' ${ }^{143}$ with particular deaths, without ever being held formally culpable or legally responsible.

Such confessions can be made to do different things in changing historical contexts, such as present a 'Rhodesia more powerful in memory that it ever was in practice' or portraying Chitepo and Tongogara 'as more heroic, more charismatic, and more judicious' than they were ever considered in their lifetimes. ${ }^{144}$ The confessions also operate across, as well as within, diverse discursive registers, and often appear like a means of evading legal responsibility. Indeed perhaps the efficacy of rumours lies exactly in their multiplicities, so that like 'confessions and secrets-revealed they can best understood both as 'tools of increased surveillance' (in Foucault's terms), and as 'spectacles', 'made so that we - their audience - can know all about the state. ${ }^{145}$ This reflects the productive duplicity of rumours I have discussed in relation to the indeterminate alterity of human remains at Chibondo, ${ }^{146}$ which enables the celebration of

\footnotetext{
137 White, The Assassination.

138 White, The Assassination, 87.

139 See, for example, White, The Assassination, 93; Nyarota, Graceless Fall; W. P. R. Srdan, 'Mugabe Still Fears Chitepo's Legacy', Zim Issue 16, 10 April 2008, http://iwpr.net/report-news/mugabe-still-fears-chitepos-legacy (accessed 18 February 2014).

140 White, The Assassination.

141 White, The Assassination, 2. White cites Trouillet's 1995 study of the Haitian revolution.

142 White, The Assassination, 9.

143 S. Ellis 'Tuning in to Pavement Radio', African Affairs 88, 352, 1989, 321-330.

144 White, The Assassination, 85, 97.

145 White, The Assassination, 84.

146 Fontein, 'Remaking the Dead'.
} 
'national heroes' and the reinforcement of anti-colonialist rhetoric at the same time as reasserting hierarchies of necro-political sovereignty.

One problem that any discussion of rumours faces, like studies of jokes and humour, is that what they mean or rather do is so context dependent; their efficacy is dependent upon their performance and reception as much as on their 'content' per se. ${ }^{147}$ The rumours surrounding Mujuru's death illustrate this very well. The immediate suspicions about murder (and who might be responsible) engaged with a wide host of pre-existing intrigues to do with ZANU PF factionalism, its deepening succession disputes, the still rebounding repercussions of its electoral failures in March 2008, of the wiki-leaks scandal, and Mujuru's alleged fallout with the president, as well as various conspiracies involving diamonds and murky business interests. In August 2011, and even months afterwards, each rumour seemed possible or even likely.

Seven years later, however, after his wife Joice Mujuru's eviction from the vicepresidency, Mnangagwa's ascendency to and then removal from the same position, followed by President Mugabe's own removal in late 2017 in favour of Mnangagwa and Chiwenga, ZANU PF's deepening factionalism around the succession issue has become the most likely intrigue lying behind the Solomon's death. Other explanations now appear less convincing, less salient, less obvious, even if other possibilities do continue to circulate. Rumours surrounding such uncertain, high-profile deaths make each of those deaths both unique events in and of themselves, and of course unique to any moment in which they are (re)considered, reconstituted, and given new or renewed significance, meaning and value. In other words, they are historically situated.

Solomon's death was, therefore, like Chitepo's assassination, Tongogara's accident, and all Zimbabwe's other mysterious deaths, a unique event that is necessarily of changing significance and meaning in changing circumstances, and is perhaps therefore best judged on its own (historical) terms. And yet all these different deaths are connected; in people's minds and conversations, but also in their form, their uncertainties, and the responses they provoke; each new mysterious death immediately indexing the last. 'Political accidents' are, I suggest, a particular kind of death in Zimbabwe. And although they resonate across the region, where the death of public figures is often surrounded by a wealth of intrigue, ${ }^{148}$ there is something particular about this form of unfinished Zimbabwean death that has to do with the profound uncertainty that surrounds them; a productive and potent, yet often disruptive, duplicitous and excessive indeterminacy.

Most obviously what unites these 'political accidents' - distinct from the unresolved violence and deaths of the liberation struggle, of the Gukurahundi, and of more recent political violence ${ }^{149}$ - is both the senior ZANU PF status of the dead, and

147 I am grateful to Justin Willis for raising this, and making me think harder about what it is that usefully defines these kinds of rumour as politically significant in particular ways.

148 On Kenya, for example, see Cohen and Odhiambo, The Risks of Knowledge.

149 Fontein, 'Between Tortured Bodies'; L. Sachikonye, When a State Turns on Its Citizens (Harare: Weaver Press, 2011); Eppel, 'Repairing a Fractured Nation'; and Eppel, 'Bones in the Forest'. 
the speed and public grief with which so many were immediately declared national heroes, despite (or maybe because of) the controversies surrounding their deaths. This has often been remarked upon by the media who gleefully report the 'mysteries' surrounding the 'litany of sinister deaths' of national heroes. ${ }^{150}$ While the apparent contradiction of a ruling party engineering the 'accidental' deaths of its own 'heroes' contributes to the broader contestations long surrounding ZANU PF's elitist control of state commemoration, ${ }^{151}$ it also offers a coherence to these particular kinds of death. In this respect, it is instructive to note that aside from the multilayered politics of exclusion surrounding the selection of national heroes - marked by elitism, hierarchism and the exclusion of high-profile members of rival parties and movements (such as ZAPU/ZIPRA) as well as former ZANU/ZANLA 'rebels' and perceived 'sell outs', such as Ndabaningi Sithole or Wilfred Mhanda (aka Dzino), sometimes in favour of only recently significant political actors like Chenjerai Hunzi, with questionable liberation credentials - another less-remarked upon dynamic is the phenomena of former party 'insiders' who later became critical voices against the party, but who are nonetheless still interred as national heroes after their deaths. This includes both Eddison Zvobgo (d. 2004) and Edgar Tekere (d. 2011) who were both buried at National Heroes Acre despite having expressed specific sentiments critiquing the Heroes selection process and denying any wish to be buried at the site. ${ }^{152}$

These two examples are, of course, different from each other, and from what I am calling 'political accidents'. Nevertheless, they are informative. Edgar Tekere was a more outspoken and longer-standing adversary of President Mugabe than Eddison Zvobgo's much more measured and careful critiques in the later years of his life. And although both were awarded national hero status, President Mugabe's response to each death was different. Highly unusually, he avoided attending Tekere's Heroes Acre burial in 2011, but had sung Zvobgo's praises at his funeral almost a decade before, describing him as a 'fearless and dedicated gallant freedom fighter. ${ }^{153}$ Both Tekere and Zvobgo had in their own ways challenged Mugabe during their lives, and at different moments harboured ambitions to succeed him. Both died after long illnesses, so neither death was surrounded by controversies common to 'political accidents', although Zvobgo had survived a car accident in the mid-1990s that for many 'looked suspiciously like several others in which challengers to Mugabe have died. ${ }^{154}$ Yet they do illustrate the opportunities that the deaths of high profile ZANU PF

150 'Litany of Sinister Deaths', Times (SA), 8 March 2009; 'Mugabe Honours Alleged Victims', Zimbabwean, 17 August 2009; 'Mystery Surrounds Deaths of National Heroes', Nehanda Radio, 15 August 2012; 'Mystery Car-Crash Deaths Haunt ZANU-PF', 27 Mail \& Guardian, June 2013.

151 R. Werbner, 'Smoke from the Barrel of a Gun' in R. Werbner (ed.), Memory and the Postcolony (London: Zed, 1998), 71-102; N. Kriger, 'The Politics of Creating National Heroes' in N. Bhebe and T. Ranger (eds), Soldiers in Zimbabwe's Liberation War (London: James Currey, 1995) 39-62; J. Fontein, 'Politics of the Dead: Living Heritage, Bones and Commemoration in Zimbabwe', ASA Online, 0102, 10 August 2009, https://www.theasa.org/publications/asaonline/articles/asaonline_0102.shtml (accessed 8 December 2018); K.Z. Muchemwa, 'Necropolitan Imagination', Social Dynamics, 36, 8, 2010, 504-514.

152 'Heroes Acre has Lost its Glory, Says Zvobgo', Zimbabwe Standard, 19-25 August, 2001. 'Mugabe Avoids Tekere Heroes Acre Burial', Nehanda Radio, 12 June 2011.

153 'President Mugabe Pays Tribute to Eddison Zvobgo', Herald 30 August 2004.

154 A. Meldrum 'Eddison Zvobgo Obituary', Guardian, 24 August 2004. 
politicians can offer to contain, stabilise and fix disruptive political legacies and potential alternative historical narratives within an acceptable 'heroic' and 'patriotic' mode; attempting to fix in death what was difficult to contain in life. Although decidedly not a ZANU PF figure, Tsvangirai's recent state-assisted funeral is another, more recent example that is also illustrative here. ${ }^{155}$ Such examples are instructive about the political affordances that accrue from the uncertainties that surround all deaths, but perhaps particularly 'political accidents', creating new opportunities for the (re) stabilisation, containment and determination of particular pasts, particular necropolitical orders, and particular kinds of dead. It is, after all, not simply sentimentality that has made Heroes Acre funerals and annual celebrations such key events for the (re)making of ZANU PF's nationalist historiography over the last three decades.

If the achievement of 'national hero status' is a defining feature of 'political accidents', then of course this also differentiates them from the killings and disappearances of different periods of political violence since independence, such as the Gukurahundi of the 1980s and the election violence of the 2000s, particularly 2008. 'Political accidents' are distinct exactly because they index struggles within ZANU $\mathrm{PF}$, establishing a more exclusive strand of 'necropolitan' order ${ }^{156}$ internal to the ruling party itself. Furthermore, unlike the dismembered, unburied, leaky of disappeared bodies of Gukurahundi and post-2000 election violence, 'political accidents' are less about the disruption of normal processes of containment and transformation through which people (dead or alive) are constituted, ${ }^{157}$ then about the making of very particular kinds of dead. And in so doing, the 'mysterious' accidental deaths of ZANU PF figures transformed into national heroes turn, like the indeterminate human remains exhumed at Chibondo, ${ }^{158}$ on a fundamental tension between necroand biopolitics - between the demands of sovereignty and of legitimacy - exactly because these dead are such high-profile political actors, ZANU PF insiders, and because they nearly always become national heroes.

Partly then, 'political accidents' are about stabilising and containing in death that what may have been perceived as troublesome and difficult to contain in life; and the conspiracy theories that surround the mysterious accidents of ruling party politicians often point explicitly in this direction. But this alone is not enough. Equally important are the duplicitous affects of uncertainty at play in the way such deaths can be made to reify ZANU PF's exclusivist, 'heroic' forms of nationalist belonging while simultaneously reaffirming a concentrated hierarchy of necro-political sovereignty within its own ranks, by pointing to where the capacity to 'exercise control over mortality' ultimately lies. ${ }^{159}$ We can therefore see how rumours about 'dodgy' accidents can do political work that turns on their productive uncertainty, just as the excessive potentialities of human remains from the Chibondo exhumations did.

\footnotetext{
155 'State Funeral for Tsvangirai', Herald, 16 February 2018; 'Hundreds Pay their Respects to Morgan Tsvangirai at Funeral', Times (SA) 19 February 2018.

156 Muchemwa, 'Necropolitan Imagination'.

157 Fontein, 'Politics of the Dead'.

158 Fontein, 'Remaking the Dead'.

159 A. Mbembe, 'Necropolitics', Public Culture, 15, 1, 2003, 11-40, at 11-12.
} 
A key issue here is that rumours of foul play surrounding 'political accidents' can only ever remain allegations. They cannot be substantiated or fixed through more authoritative mechanisms, judicial or otherwise, because that might mean issues of legitimacy would outweigh any necro-political advantages. Any such fixing, however contingent, could undermine the productive uncertainties at play in these situations. 'Political accidents' must therefore, almost by definition, remain unfinished and unresolved in order to be political efficacious. In this respect it is no surprise that the inquest into Solomon's death, although officially concluding it was accidental, hardly offered resolution to anyone's satisfaction; just as the National Museums and Monuments of Zimbabwe's reburial and memorialisation of the remains at Chibondo, and the sealing of the mine, ultimately has only delayed rather than resolved the controversies provoked by those exhumations; and just as the 1976 Chitepo Commission report failed decidedly to curtail decades of subsequent intrigue surrounding Chitepo's assassination.

Reflecting more broadly across the region and beyond, what marks Zimbabwe's 'political accidents' off from a plethora of other rumoured assassinations is that they are (nearly) always officially framed as 'accidents' (Chitepo's death being the obvious exception). Moreover their 'accidental' nature although questionable (and usually questioned) always remains a possibility. The unresolved uncertainties surrounding these deaths are not confined to why and by whom someone is killed, but whether malevolent intentionality was involved at all. Therefore despite the continuing fervour of intrigue around both Tongogara and Mujuru's deaths, for some evidence of 'foul play' in either case remains thin and unconvincing. ${ }^{160}$ In comparative examples across the region, such as Kenya, it is more common for rumours to surround the death of someone recognisably a victim of intentional killing (having been shot, for example) so that any unresolved questions revolve around the question of who lies behind it, and the why. ${ }^{161}$ With Zimbabwe's 'political accidents', by contrast, the possibility of 'chance' and misfortune (as well as 'occult' intervention) always retains potential traction. ${ }^{162}$ This makes the uncertainties surrounding these deaths more profound, in turn extenuating the potential political efficacy deriving from the duplicity of the rumours in which they are immersed. Because a possibility always remains that any particular individual's 'accidental' death really was an accident (even as it is assumed not all of were) the duplicitous salience of this kind of death is amplified, fuelling both the necro-political affects and enabling 'patriotic' proclamations of heroism to be endlessly reinforced. Of course, such uncertainty also means that any political affects remain potentially disrupt-able. The indeterminacy surrounding such deaths is both of great potential political salience and yet, in the end, excessive to it.

160 Nyarota, Graceless Fall.

161 A good example was the torture and death of Chris Msando, a senior election official, a few days before Kenya's 2017 election. See 'Kenya Election Official Tortured, Murdered Before Vote, Officials Say', Reuters, 31 July, 2017, https://www.reuters.com/article/ us-kenya-election-death-idUSKBN1AG1B5 (accessed 10 September 2018).

162 An informative counter-example is the considerable effort Kenyan authorities spent on trying to persuade Julie Ward's father that her death was accidental - a very unlikely scenario; Musila, A Death Retold. 


\section{Conclusions}

'Political accidents' are therefore particular kinds of death in Zimbabwe, the key elements of which include: the high profile status of the 'victim', usually within the ruling ZANU PF party; which is then cemented (although rarely without controversy) through burial at National Heroes Acre; and the apparently 'accidental' nature of the death - most usually car accidents, but not always - which remains subject to unresolved controversy amidst rumours of assassinations, internal party politics, and suggestions of malign (sometimes occult) involvement linked to individual interests, agendas, and ambitions. Most important, however, is that these rumours are never stabilised into any singular authoritative account. Where public enquiries have been held, they themselves, as with Mujuru's inquest, have been subject to feverish rumour and conspiracy, and have managed neither to demonstrate malign intent was involved in any particular case (let alone identify responsibility), nor successfully establish public confidence in the 'accidental' nature of the death. In short, these high-profile deaths are always left indeterminate and therefore unfinished. Moreover, they would lose their political saliency if they were ever fixed. The uncertainty that surrounds them is key to their saliency.

The argument developed here turns on the notion that the uncertainties of these kinds of death, can offer political salience and opportunity even as they must remain, by their nature, duplicitous, indeterminate and ultimately excessive to any intentional scheme, containment or 'fixing. Building on Mbembe's work, ${ }^{163}$ this suggests that political actors may have much to gain from rumours that circulate around 'political accidents'. It illustrates how uncertainty can be a fundamental feature of the stylistics of postcolonial power, particularly as forged in the ambivalent space between the legitimating dimensions of 'bio-power' and assertive demonstrations of 'necro-political' sovereignty. But it also suggests that the 'useful' rumours surrounding unexplained deaths of public figures are not entirely divorce-able from the profound uncertainties that all deaths can precipitate, particularly in Zimbabwe and especially in the context of rapidly changing, multiply regimes of death across the region. Such uncertainties defy containment, stabilisation, or the 'fixing' of definitive narratives, and any final 'remaking' of the dead into 'heroes', 'victims' or 'ancestors'. And they easily 'leak' the confounds of space and time, as leaky bodies contaminate the troubled landscapes of militia camps, mass graves and car wrecks, and as unhappy, avenging spirits, troubling ghosts, or new witness accounts, or even new confessions to murder, appear at odd moments to defy regulated temporalities. All this points to the potential excessiveness of death itself, its open-endedness, and its profound lack of finality and closure, or even 'incompleteness' (Nyamnjoh). ${ }^{164}$ It is

163 A. Mbembe, On the Postcolony (Berkeley, CA: University of California Press, 2001); Mbembe, 'Necropolitics'.

164 F. B. Nyamnjoh 'Incompleteness: Frontier Africa and the Currency of Conviviality', Journal of Asian and African Studies 52, 3 , 2017, 253-270. 
in this sense, perhaps, that death is rarely entirely finished with, which has important implications for the potential resolution that is often assumed to be offered by exhumation and reburial. ${ }^{165}$ It seems unlikely, therefore, that even if the Mujuru family's demands to exhume and re-examine Solomon's remains were ever actualised - a unlikely scenario for now - this would offer any more closure or finality than the inquest into his death did in 2012.

165 This is not to deny that exhumations and reburials can sometimes play an important role in processes of post-conflict resolution. My argument about the uncertainties of death, and particularly violent deaths, and the political salience that can derive from this, points more to a critique of common expectations of 'healing' and 'closure' that are often assumed to derive from exhumations and reburials. Such processes can precipitate turbulence and violence as often as they offer resolution (see for example Verdery's account in The Political Lives of Dead Bodies, in which she describes how such processes fed into ethnic and nationalist violence in Yugoslavia in the early 1990s). Eppel's long experiences in Matabeleland, and particularly the exhumations that were possible for a short period in the late 1990s show that they can, under particular circumstances and contexts, and as part of wider, multifaceted, and sensitive, long-term processes of community engagement, offer resolution to relatives and affected communities (see Eppel 'Repairing a Fractured Nation' and 'Bones in the Forest'). Exhumations and reburials of the Gukurahundi dead certainly continue to be in much demand in that region, even as their continued obstruction by ZANU PF points exactly to the political efficacy of unresolved deaths highlighted in this article. Creating the kind of 'mediated space in which grievances and conflicting versions of "truth" about the violence can be shared, which Eppel identifies are essential for processes of resolution and reconciliation, of which exhumation and reburial may be a part, is very difficult to achieve in the best of circumstances and requires a huge amount of careful documenting and community work. Eppel, 'Repairing a Fractured Nation', 238. Such difficulties point exactly to the unfinished nature of death that I seek to highlight here, which turns, in part, on the excessivity or 'torque' (as Pinney calls it), or 'otherness' (as Renshaw says) of human remains. 